\title{
Polska poezja na Wyspach: podczas wieczorów panuje tu nostalgia
}

Anna Kałuża

TEKSTY DRUGIE 2016, NR 3, S. 187-204

DOI: $10.18318 /$ td.2016.3.11

osy polskiej poezji za granicą trudno byłoby dziś objaśniać, odnosząc je do emigracyjnych narracji'. Mniej więcej od 1989 roku wyjazdy Polaków nie wynikały wyłącznie z przesłanek politycznych, a interpretowanie ich po 2000 roku w perspektywie emigracyjnych klisz historycznych (romantycznych, narodowowyzwoleńczych czy dysydenckich) odrywałoby je zupełnie od rzeczywistości kulturowej. To raczej ekonomia wydaje się najtrafniejszym kluczem do analiz pobytów zagranicznych. Nie znaczy to jednak, że klucz ten jest wystarczający do tego, by opisać powstającą za granicą poezję, zwłaszcza jeśli chcielibyśmy ją rozumieć jako estetyczno-ideologiczny fenomen kulturowy. Zjawiska ekonomiczne i społeczne

1 Zob. liczne książki o emigracji po 1989 roku, m.in. Narracje migracyjne w literaturze polskiej XX iXXI wieku, red. H. Gosk, Universitas, Kraków 2012; H. Mamzer Tożsamość w podróży. Wielokulturowość a ksztattowanie tożsamości jednostki, Wydawnictwo Naukowe UAM, Poznaŕ 2003; Pisarz na emigracii. Mitologie. Style. Strategie przetrwania, red. H. Gosk, A.S. Kowalczyk, Elipsa, Warszawa 2005; A. Nęcka Emigracje intymne. O wspótczesnych polskich narraciach autobiograficznych, Wydawnictwo UŚ, Katowice 2013.

\author{
Anna Kałuża - \\ dr hab, adiunkt \\ w Zakładzıe Literatury \\ Współczesnej Uni- \\ wersytetu Śląskiego. \\ Sekretarz redakcji \\ "Śląskich Studiów \\ Polonistycznych". \\ Opublikowała m.in. \\ Bumerang. Szkice \\ o poezji przelomu \\ XXiXXI wieku (2010), \\ Wielkie mygrane. \\ Wspólne sprawy \\ poezji, krytyki iestetyki \\ (2011) oraz Pod gra. \\ lak dziś znaczq wiesze, \\ poetki i poeci (2015). \\ Kontakt: Anna_Kalu- \\ za@poczta.onet.pl
}


warto z pewnością wyjaśniać kulturowo, ale nad sytuacją poezji - będącą złożoną konfiguracją komunikacyjną - chciałabym zastanawiać się, uwzględniając więcej czynników.

\section{Cross culture i ekonomia}

Za Stephenem Greenblattem sytuację poezji polskiej w obcojęzycznym środowisku można charakteryzować za pomocą " poetyki kultury”" oraz łączyć ze zwrotem mikrohistorycznym, stanowiącym alternatywne podejście podobne jak geopoetyka - do narracji klasycznej historii kulturowej upowszechniającej przekonanie o homogeniczności kultur ${ }^{3}$. Można również przy tej okazji „przetestować” założenia transkulturowych estetyk, kierujących naszą uwagę np. na pojęcia cross culture. Owocne byłoby także przyjrzenie się temu zjawisku z perspektywy literackich praktyk codzienności (w rozumieniu m.in. Michela de Certeau ${ }^{4}$. Wydaje mi się, że próbując pozycjonować poezję polską powstającą za granicami Polski (lub pomyślaną jako konsekwencja takich wyjazdów), należy porzucić myślenie odwołujące się do historycznie skonstruowanych pojęć emigracji (i jej kontekstów polityczno-świadomościowych) i zastąpić je np. pojęciami „spotkania kulturowego" czy „translacji kultur"5.

Osłabiając funkcjonalność historycznych odniesień do emigracji, uzyskamy perspektywę, która pozwoli uwzględnić kulturowo-komunikacyjne różnice o charakterze politycznym, zachodzące między wspólnotami niekoniecznie zdefiniowanymi zgodnie z kryterium narodowym. Najwaźniejsze jest tu moim zdaniem zmienione pod wpływem nowych mediów rozumienie przestrzeni/miejsca, czasu, tożsamości indywidualnej i zbiorowej wspólnot. Radzi sobie ono lepiej niż emigracyjnie skonstruowane mapy, oparte na dychotomicznym podziale przestrzeni, z dostrzeganym przez antropologów „zniknięciem” przestrzeni - rzekomo zastąpionej prędkością, mobilnością, ruchem i przyspieszeniem. Lokalności i partykularności w tym poszerzonym

2 Zob. S. Greenblatt Poetyka kulturowa. Pisma wybrane, przeł. K. Kujawińska-Courtney, Universitas, Kraków 2006.

3 Zob. P. Burke Historia kulturowa. Wprowadzenie, przeł. .. Hunia, Wydawnictwo UJ, Kraków 2012, s. 8 .

4 Wskazuje to wyłącznie na rozległe pole możliwości sfunkcjonalizowania współczesnych teorii estetyczno-kulturowych, zastępujących historyczne opisy emigracji i ich aktualizacji.

5 Zob. P. Burke Historia kulturowa..., s. 135-143. 
horyzoncie spotkań kulturowych rozumiane są bowiem jako siły nieustannie dokonujące rewizji pola uformowanego przez transnarodowe czy transetniczne idee, a nie jako siły zagrażające tym polom.

Przytoczone teorie translacji kultur czy literackich praktyk codzienności wpływają przede wszystkim na koncepcyjne ramy myślenia o tym, jak ujmować powstające za granicami Polski teksty, ale nie biorą pod uwagę politycznych i ekonomicznych warunków produkcji kulturowej. Mankamentem wielu spośród tych teorii może być bowiem niedocenienie otoczenia pragmatyczno-społecznego, które reguluje i dopuszcza pojawianie się obiektów w przestrzeni publicznej. Dlatego - przywodząc perspektywę spotkań kulturowych - trzeba mieć na uwadze również politykę kulturalną państwa oraz kontekst aktualnego układu geopolitycznego i ekonomicznego (Unia Europejska, otwarte granice, polityka integracyjna, polityka zarobkowa). Choć środowiska artystów są rozproszone, to za granicą autorzy mogą liczyć przede wszystkim na instytucje polskie (Instytut Książki czy Instytut Adama Mickiewicza). Globalne przepływy kapitału, idee transnarodowości i metropolitalne układy europejskich miast zdają się pracować - jeśli już - na korzyść raczej sztuk wizualnych niż literatury. Narodowe interesy różnych państw w dalszym ciągu pozostają zasadniczą siłą w grze estetyczno-ideologicznej wytwarzania wartości literatury. Ograniczenie wsparcia ze strony międzynarodowych stowarzyszeń, fundacji czy innych instytucji prywatnych na rzecz wsparcia uzyskiwanego z państwowych instytucji staje się coraz bardziej widoczne, zwłaszcza w polskiej kulturze. Kategorie narodowo-państwowe - a nie interesy rozmaitych ruchów: feministycznych, anarchistycznych, ekologicznych, finansowanych przez rozmaite fundacje - są więc najbardziej oczywiste w myśleniu o polityce kulturalnej, w jakiej funkcjonuje polska poezja i jej zagraniczne dopływy ${ }^{6}$. Odpowiada to sposobowi „odgórnego" finansowania (ttumaczenia, granty, stypendia), które co prawda daje szansę na zróźnicowane ideologie estetyczne, ale w dalszym ciągu ukierunkowuje myślenie o poezji w kategoriach ogólnonarodowych. Nie inaczej jest także poza Polską: Katrine Øgaard Jensen przedstawia w 2015 roku nową duńską poezję na scenie amerykańskiej i choć zajmują ją w tej poezji sprawy ekologii, feminizmu, warunków współistnienia z innymi żywymi formami na ziemi, to krytyczka nie może pozbyć się łatki „duńskości”.

6 Wyjątkiem jest poezja realizowana w mniej tradycyjnym medium - np. festiwale elektronicznej poezji, festiwale Spoke'n'Word. Zob. np. http://www.oslopoesifilm.no/ (7.02.2016). Te praktyki osadzone są niejako automatycznie w środowisku transkulturowym. 
Co istotne, jej prezentacja nie ma żadnych punktów stycznych z narodowymi czy państwowymi kwestiami?.

Państwo jako najważniejsza w zapewnianiu symbolicznego i ekonomicznego kapitału instytucja to jednocześnie najistotniejszy podmiot biorący udział w procesie wyznaczania i dystrybuowania wartości kulturowych. Nie oznacza to oczywiście działania cenzury w zdroworozsądkowym sensie: jako wykluczania treści, obrazów czy idei, które najpierw się pojawią, a następnie zostają objęte zakazem. Precyzyjnie ujmuje to Judith Butler, gdy w Walczacych stowach pisze, że nie sposób rozumieć cenzury wyłącznie w kategoriach jurysdykcyjnej władzy. Cenzura w jej przekonaniu to warunki możliwości pojawienia się mowy uznawanej za akceptowalną. Nie tyle działa ona po zaistnieniu jakiejkolwiek produkcji kulturowej, ile przed jej zaistnieniem ${ }^{8}$. Dlatego tak ważne jest zwrócenie uwagi na instytucje państwowe stojące u początku procesu wytwarzania i cyrkulacji tych produktów, które uznajemy za znaczące fakty kulturowe. Zwłaszcza gdy fakty te powstają na przecięciach instytucji, kultur i języków. Gdyby politykę finansowania kultury, a w tym przypadku politykę rozmaitych programów stypendialnych skierowanych do poetek i poetów, udało się skonstruować także z większym naciskiem na inne kryteria niż narodowe (np. artystyczne, społeczne czy etniczne), to wówczas mogłyby się powieść bardziej różnorodne sposoby konceptualizowania poezji. Ostrożniej przyszłoby nam też formułować tezy o zaleźności między miejscem a doświadczeniem i obrazami poetyckimi. Co oznacza, że emigracyjne klisze wyjazdu z kraju i tęsknoty za czasem dzieciństwa stałyby się wyłącznie przedłużeniem jednej z historycznych konwencji, a nie najbardziej oczekiwanym tekstowym zachowaniem poety/poetki. To właśnie m.in. polityka narodowo-państwowych instytucji autoryzuje konwencjonalizm i tradycjonalizm w myśleniu o poezji.

7 K. $\varnothing$. Jensen After Inger Christensen: Humans, Plants, and Planets in New Danish Poetry, http:// www.wordswithoutborders.org/article/december-2015-danish-intro (7.02.2016).

8 „W obiegowym ujęciu przyjmuje się, że cenzura jest stosowana przez państwo wobec tych, którzy są słabsi. [...] Zgodnie z obiegowym ujęciem cenzura wydaje się pojawiać później niż napastliwa wypowiedź: mowa już stała się napastliwa i dlatego pojawia się odwołanie do pewnej regulacyjnej instancji. Natomiast w ujęciu podkreślającym, że cenzura wytwarza mowę, ta czasowa zależność ulega odwróceniu. Cenzura poprzedza tekst (przez co rozumiem i mowęr i inne ekspresje kultury), będąc w pewnym sensie odpowiedzialna za jego produkcję". Dla Butler cenzura to reguły, które pojawiają się przed jakąkolwiek indywidualną decyzją i które "stanowią właśnie ograniczające warunki tworzące możliwość podejmowania jakichkolwiek konkretnych decyzji". I. Butler Walczqce stowa. Mowa nienawiści i polityka performatywu, przeł. A. Ostolski, Wydawnictwo Krytyki Politycznej, Warszawa 2010, s. 148-149. 


\section{Gry estetyczne i konfrontacje kultur}

Trudności z pozycjonowaniem poezji (powstającej za granicą) wiążą się nie tylko z funkcjonalnością odwoływania się do emigracyjnych narracji czy z problemami polityki kulturalnej państwa. W ramach, jakie wyznacza pojęcie spotkań kulturowych, można zbyt szybko przejść do porządku dziennego nad konfliktowym charakterem tych spotkań i kulturową hegemonią określonych języków. Przykładowo geopoetyka docenia przede wszystkim potencjał wymiany kulturowej, dokonującej się dzięki otwarciu granic narodowych i wypracowaniu silnego statusu metropolii, a także lokalnych identyfikacji kulturowych wspólnoty9. Nie ma tu jednak miejsca na pytanie o antagonizmy i agonizmy kulturowe. Warto więc także - być może w przyszłości - zasta nowić się nad tym, w jaki sposób polska poezja włącza się w dyskusję nad konfliktami kulturowymi, problemami tożsamościowymi etc. i jakie są w takim układzie geopolitycznym konsekwencje dominacji języka angielskiego i zachodnioeuropejskiej kultury dla polskiej kultury.

W perspektywie poezji takie dyskusje podporządkowane były tezie Karola Irzykowskiego o plagiatowym charakterze przełomów polskich. Zdanie to położyło się cieniem na analizie związków między obszarami języka angielskiego i polskiego w paśmie poetyckim. Stanowiło alibi dla redukowania tych analiz do tropienia długów, jakie polskie teksty zaciągały w zagranicznych oryginałach. Przykładem tego kuriozalnego mechanizmu sprawdzeń może być tocząca się po roku 1989 dyskusja o „wpływie” na polską poezję amerykańskiej poezji Franka O'Hary i Johna Ashbery'ego. Pomijając slapstickowy charakter tej dyskusji, gdy słowo „o'harysta" pod piórem Krzysztofa Koehlera stawało się żartem wziętym jakby prosto z kreskówek Disneya, trzeba zauważyć, że dyskusja ta była umocowana w świadomości „puryfikatorskiej”, hierarchizującej monocentrycznie pomyślane kultury i oddzielającej obce wpływy od nieobcych ${ }^{10}$. Tymczasem gest polskich autorów wskazujących na twórców z innego obszaru językowego i artystycznego oznaczał potrzebę „poluzowania" binarnych i konfrontacyjnych ustawień kulturowo-narodowych ${ }^{11}$.

Zob. E. Rybicka Geopoetyka, w: Kulturowa teoria literatury. Gtówne pojęcia i problemy, red. M.P. Markowski, R. Nycz, Universitas, Kraków 2006, s. 471-490. $1990 \mathrm{nr}$ 14-15; M. Świetlicki Koehleryzm, „brulion” $1991 \mathrm{nr} 16$. 
Wnioski z tej ostatniej, jak do tej pory, niezbyt fortunnej wymiany uwag na temat zapożyczeń w poezji polskiej, płyną takie, że dopiero gdy zrezygnujemy z opisu poezji w horyzoncie ścierania się wartości homogenicznych kultur (bardziej czy mniej plagiatowych, oryginalnych i naśladujących, wtórnych i wiodących), możemy sensownie przyglądać się grom estetycznym, ujawniającym się w procesach translokacji różnych wartości i polityk społeczno-kulturowych. A stawka takich dyskusji jest wysoka, poniewaź wartość tekstów poetek i poetów „przemieszczających” się językowo i geograficznie - jak wiemy z przeszłości - bywa nieoceniona dla poezji. Po 1989 roku to właśnie grono poetów-tłumaczy przebywających na stypendiach, wyjazdach zagranicznych czy stażach zaaranżowało nowe warunki funkcjonowania poezji jako instytucji.

Trzeba jednak przyznać, że dziś - po rewolucji nowomedialnej - w takim monocentrycznym wzorcu wpływu i naśladowania trudno byłoby serio rozpatrywać dominację jakiejś filozofii poetyckiej. Poezja polska od 1989 roku utrzymuje napięcie estetyczne z poezją innych języków, zwłaszcza amerykańską spod znaku innowacyjnego, awangardowego postmodernizmu szkoły nowojorskiej, odnajduje się w międzynarodowych slamach, poezji politycznie czy obywatelsko zaangażowanej (civic poetry), czuje się dobrze w środowiskach elektronicznych ${ }^{12}$. Cały czas to jednak faza początkowa różnych pomysłów. Jeśli chodzi o eksperymenty wiążące ze sobą naukę i sztukę, to polskim artystom nie udaje się wypracować wielu związków między tymi dziedzinami; jeśli chodzi o eksperymenty poezji ze środowiskami wirtualnymi (video poetry, flash poetry, gify poetyckie etc.) - jedynie Wydawnictwa Ha! art czy Hub Wydawniczy Rozdzielczość Chleba prowadzą taką działalność. Z kolei feministyczna i zarazem ekokrytyczna poezja znajduje poparcie wyłącznie w środowiskach akademickich, co nie jest oczywiście zjawiskiem niekorzystnym,

nów, jaki odczytuje z wiersza Kennetha Kocha, ale myślę, że efekt „asa w rękawie”, jak nazywa on odwołania nowojorczyków do poezji francuskiej i rosyjskiej, miał zadziałać tak samo i w polskiej poezji po 1989 roku.

12 Można na to napięcie spojrzeć nieco mniej optymistycznie i zauważyć, że nadal w Polsce wielu twórców istotnych dla światowej poezji z obszaru języka angielskiego jest nieznanych, nietłumaczonych i „nieprzetworzonych". Na przykład inni niż Ashbery i O'Hara poeci ze szkoły nowojorskiej (Barbara Guest) lub inspirujący się szkołą nowojorską poeci nurtu Language, jak m.in. Charles Bernstein czy ich następcy, jak m.in. Ron Silliman, nie mówiąc już o młodej scenie poetyckiej w Wielkiej Brytanii, na której m.in. Francesca Lisette, Amy De'Ath، Julia Ciesielska, Frances Kruk czy Rebecca Goss. Lista "nieobecnych" z pewnością jest bardzo długa i nie ma sensu jej wydłużać. 
choć ta izolacja jest już efektem działania niekorzystnych procesów kulturowych, hamujących odważniejsze myślenie artystyczno-polityczne poza obrębem uniwersytetu. Jedną z konsekwencji takich procesów jest to, że nie można podobnych propozycji poetyckich skonfrontować z innymi, bardziej radykalnymi, bo takich w Polsce nie ma (np. spod znaku idei anarcho-feministycznych czy innych koncepcji poezji radykalniej pomyślanej). Słowem, w polskiej poezji rzadko możemy obserwować rozmaicie rozumiane eksperymenty estetyczno-polityczne (z paroma wyjątkami). Na pocieszenie trzeba powiedzieć, że polska proza jest jeszcze bardziej tradycjonalistyczna i pisana w przekonaniu o niezbywalnej wartości idei uniwersalnych, ujmowanych oczywiście w ahistoryczny sposób.

Ta potencjalnie nieodległa relacja polskiej poezji z innojęzycznymi poetyckimi ideologiami jest możliwa dzięki „miękkim granicom”, które tworzy Internet. Dostęp do różnych poetyk jest od jakiegoś czasu teoretycznie nieograniczony i to, czy „innojęzyczni/innojęzyczne" poeci/poetki są czytani/ czytane przez polskich autorów, nie musi koniecznie od razu materializować się w postaci przekładów lub odwrotnie - że to wyłącznie przekłady decydują o istotnej pozycji pewnych autorów na obszarze polskojęzycznym. Od jakiegoś czasu zależności, związki i zaangażowanie estetyczno-kulturowe są z jednej strony bardziej dyskretne, a z drugiej - niezobowiązujące i niejawne.

Pozostając w kontekstach międzykulturowych, zastanówmy się zatem, czy autorzy, którzy wyjechali po 2000 roku na Wyspy, wprowadzili nowe sposoby ujmowania poezji, czy dzięki nim zaistniały nowe "modne" nazwiska, czy zadecydowali o rozpowszechnieniu jakiegoś nowego nurtu. Miejmy na uwadze to, że trendy z lat 9o. tworzyli poeci-tłumacze, których niewielu wśród autorów wyjeźdżających do Wielkiej Bry tanii po 2000 roku. Co istotne, w związku z ciągłymi migracjami należałoby włączyć w opis i analizę sytuacji „zagranicznej” poezji polskiej także autorów i autorki, którzy do Wielkiej Brytanii przyjeżdżają na kilkumiesięczne stypendia. Bardziej migracje i tranzyty niż stała obecność wyznaczają tu trasy zbiegania się i rozbiegania różnych poetyckich akcji.

\section{Rozszerzający się wszechświat i dydaktyczna poezja}

Spośród tych, którzy przebywali przez jakiś czas na Wyspach Brytyjskich po 2000 roku, trzeba wspomnieć Klarę Nowakowską, Roberta Rybickiego, Kajetana Herdyńskiego, Arkadiusza Kremzę, Kamilę Pawluś. O swoim pobycie poza krajem jako tymczasowym mówi również Grzegorz Wołoszyn. Z kolei 
Sławomir Elsner, Małgorzata Południak, Izabela Smolarek, Wioletta Grzegorzewska i Tomasz Mielcarek uznają swój pobyt za granicą za względnie stały ${ }^{13}$. Nie wszyscy pisali i wydawali, przebywając poza krajem: Elsner wyjechał do Irlandii już jako autor arkusza Afekt i debiutanckiego zbioru Antypody i aktualnie pracuje w Irlandii nad swoją drugą książką. Jacek Bierut w rozmowie z Elsnerem mówi o Klarze Nowakowskiej, że podczas swojego pięcioletniego pobytu w Londynie nie napisała ni $c^{14}$. Z kolei Kamila Pawluś, autorka dwóch zbiorów poetyckich, podczas dwuletniego pobytu w Londynie napisała cykl wierszy ${ }^{15}$. Autorek i autorów publikujących na stronach internetowych, chwilowo lub na stałe przebywających na Wyspach, jest oczywiście znacznie więcej niż tu komentowanych, nie sposób jednak ułożyć z ich alktywności względnie stabilnej mapy polskiej poezji za granicą.

Gdyby szukać dwóch radykalnie różnych sposobów myślenia o poezji, to nie moglibyśmy znaleźć bardziej odległych niż te, które kształtują wiersze Roberta Rybickiego i Grzegorza Wołoszyna. Pozostałe propozycje mieszczą się między tymi dwoma niesprowadzalnymi do siebie wyobrażeniami o poezji.

Stos gitar (2009) Rybickiego - autora wielu zbiorów poetyckich, pisanych także w Polsce, aktualnie przemieszczającego się między Polską a Czechami - ożywia duch anarchistyczny, antyinstytucjonalne tradycje dada. Pozwala to autorowi na wiele w zakresie strategii retorycznych. Uruchamia też od razu kontekst, w jakim czytamy wiersze, wiedząc, że chcą się one bronić przed byciem formą komunikacji, gotową do przechwycenia przez siły dążące do zachowania społecznego i artystycznego status quo. Tradycje dada oddalają też od tej poezji kryteria etyczne. Rybicki dystansuje sięw swojej książce zarówno od artystycznych form obecnych w głównym nurcie polskiej poezji, jak i od

13 Zob. Z. Surowiec Nostalgia w wierszach niżańskiego poety, http://www.echodnia.eu/podkarpackie/wiadomosci/stalowa-wola/art/8598820,nostalgia-w-wierszach-nizanskiego-poetygrzegorz-woloszyn-prezentowal-nagrodzony-tomik, id,t.html; Wielka Brytania moim drugim domem.ZTomaszem Mielcarkiem rozmawia loanna Kosmalska, http://archiwum-emigracja.uni. lodz.pl/en/wp-content/uploads/2015/01/a_rozmowa_z_Mielcarkiem.pdf (7.02.2016); Czuje się pisarka polskq z krwi i kości. Z Wiolettg Grzegorzewskg rozmawia foanna Kosmala, http://archiwum-emigracja.uni.lodz.pl/en/wp-content/uploads/2015/01/Arterie-19_Wywiad-z-Wioletta-Grzegorzewska_loanna-Kosmalska.pdf (7.02.2016).

14 Zob. Sławomir Elsner/lacek Bierut. Pogawędka, http://fundacja-karpowicz.org/slawomir-elsner-jacek-bierut-pogawedkal (7.02.2016).

15 K. Pawluś Wiersze, http://www.dwutygodnik.com/artykul/5276-wiersze.html (7.02.2016). 
najbardziej doinwestowanych symbolicznie (w sferze publicznej) strategii polityczno-etycznych.

To, co w Stosie gitar jest zapowiadanym gestem dadaistycznym, zmierzającym do odrzucenia wszelkich stanowisk i zastąpienia ich czystą negacją, w niepublikowanych wierszach z późniejszych zbiorów - Dar meneli i Nowy Tristian Tzara potrzebny od zaraz (pisanych w Czechach) - przedostaje się w głąb języków: niemieckiego, czeskiego, polskiego, hiszpańskiego, angielskiego etc. W efekcie wiązania między poszczególnymi słowami z poziomu składniowego schodzą na poziom brzmieniowy. Zacytujmy fragment z Happy dada:

[...] No-one knows how it grows,

frazofrenik $\mathrm{z}$ fraktalem frędzla fryzury Freuda, ale fala $\mathrm{z}$ woala à la Aal im Allee, sallam fallus als minulost,

co ona gada w tym anglodada, czarna čočka w ciemnościach ćmi ako die i Didi i MIDI LIDI

und da:

nomada gada dada als Versager [...]

Trzeba wspomnieć, że dadaistyczne idee odżywają dziś dość spektakularnie i w tym sensie strategie Rybickiego nie są odosobnione ${ }^{16}$ : RetroDada $\mathrm{Ma}$ nifesto McKenzie'ego Warka, australijskiego teoretyka mediów, jest tu jednym z wielu przykładów aktualności tego typu inspiracji.

Przywołuję te wiersze, mimo że nie wchodzą one do zbioru pisanego podczas pobytu w Londynie. Stanowią one bowiem dowód na konsekwentnie pogłębianą „eksterytorialność” poezji Rybickiego. Z perspektywy tych późniejszych książek Stos gitar, pisany podczas pobytu poety na Wyspach Brytyjskich, wydaje się jeszcze osadzony w topograficznej metaforyce. Labirynt i więzienie to najważniejsze $\mathrm{z}$ architektonicznych figur pojawiających się w tym zbiorze. Zresztą to właśnie na różnicy obramowań Rybicki komponuje Stos gitar: rozstrojenia świadomości uzyskują znaczenia, wtedy gdy zostaną

16 M. Wark RetroDada Manifesto, http://www.publicseminar.org/2016/02/retrodada-manifesto/ (7.02.2016). 
przetłumaczone na kod architektoniczno-kulturowy albo kosmologiczno-biologiczny. Frazom Rybickiego trudno przetrwać wyłącznie w ramach kanonicznych zestawów, energii dostarcza im marnotrawienie środków, z których mogą korzystać, a są nimi: tradycja sztuki i tzw. humanistycznego dorobku ludzkości, względnie stabilne „ustawienia” kodu językowego etc. Tak czy inaczej, opowieść podmiotu ze Stosu gitar stale podważa samą siebie i likwiduje swoje uwiarygodnienia. Z powodzeniem udaje się ją przeczytać jako wyraz odrzucenia krytyki cywilizacji opartej na racjonalnych argumentach na rzecz przywrócenia wagi żartom, grom i komiczno-groteskowym hiperbolom, a więc tym wszystkim środkom, którymi poważna, edukacyjno-militarna sztuka pogardza. W centralnym, dysutopijnym poemacie Maszyny na parkiecie Rybicki snuje ciekawą fantazję na temat moźliwości porozumiewania się w przyszłości, gdy życie rozciągnięte jest na całą Galaktykę. Panują wówczas dwa języki: ziemski (,zmutowany angielski z resztą / wessanych języków państw dominujących przez kilka tysięcy / lat w głębokiej przeszłości”) oraz Kod Porozumienia, „składający się z miliona/znaków, które są wprogramowane w odpowiedni segment kodu / genetycznego" (s. 34) Kod Porozumienia razem z m.in. księgami Nowej Etyki, Nowym Mengelem to znaki świadomości całkowicie skolonizowanej, infliltrowanej przez kody genetyczne.

Wizja cyber-narko-schizo-cywilizacji, zawarta w Stosie gitar, raczej apolityczna i nakierowana na intensyfikację poruszenia społecznego, zamknięta jest metatekstowym chwytem buffo. Chwyty tego rodzaju działają w zbiorze Rybickiego jak nieposłuszne posłuszeństwo ${ }^{18}$. Rybicki rozumie jednak, że prostymi chwytami destrukcyjnymi nie poradzi sobie z porządkiem symbolicznym. Dlatego jego strategia zmierza do tego, by rozmaite kody: społeczne, kulturowe, psychiczne i polityczne implementowały się nawzajem. Ta wirusowa przewrotność ma utrudnić zachodzenie procesów normalizujących i stabilizujących określone reguły w obrębie różnych sektorów naszego życia.

Rybicki nie stroni więc od społecznych konkretów, porusza się względnie zrozumiałym traktem komunikacyjnym, zwłaszcza gdy daje tzw. wielkie metafory architektoniczne (Londyn-labirynt-Babilon) czy biologiczno-technologiczne (nowi ludzie cybernetycznej ery), stroni jednak od „wyrażania”

17 R. Rybicki Stosgitar, Staromiejski Dom Kultury, Warszawa 2009.

18 Zob. I. Butler Żądanie Antygony. Rodzina międzyżyciem a śmiercia, przeł. M. Borowski, M. Sugiera, Księgarnia Akademicka, Kraków 2010, s. 87. Dla Butler oddzielenie tego, co psychiczne i symboliczne, od tego, co społeczne, umożliwia „pragmatyczną normalizację pola społecznego". 
stanowiska. Jak widać, nie pisze on wierszy politycznych, choć niewątpliwie poezję rozumie w kategoriach artystycznej polityczności.

Z kolei Grzegorz Wołoszyn w swojej debiutanckiej książce, Poliptyku (2012), większość wierszy zbudował z obrazów o charakterze moralnym. Nie mamy wątpliwości, że poecie chodzi przede wszystkim o etyczne nacechowanie przedstawianych sytuacji (gdy podmiot wierszy towarzyszy śmiertelnie chorym) czy wizji (miasta-potwora). Podporządkowujący sobie wszystkie znaczenia kod moralistyczno-edukacyjny odgrywa w wierszach zasadniczą rolę i odpowiada za przeprowadzoną w imię konserwatywnych wartości krytykę współczesnej rzeczywistości. Poliptyk jest też książką, która dowartościowuje ideę kanoniczności jako podstawową dla doniosłości poetyckiego przekazu. Parafraza Ocalonego Różewicza (przemienionego na Sclonego: bohater to świadek-ofiara zwirtualizowanej rzeczywistości), wykorzystanie romantycznego kodu, zabiegi stylizacyjne i różnorodność miar wierszowych wprzęgnięte są tu w pracę wiersza na rzecz waloryzowania i hierarchizowania rzeczywistości. Dokonuje się ona na linii: przeszłość prawdziwego, autentycznego życia i teraźniejszość uprzedmiotowionej, zmechanizowanej egzystencji oraz pastoralna, niemal arkadyjska wiejskość (ale tylko w sensie ideologicznym, bo poetycko realistyczna) i alienująca miejskość. Zacytujmy: „Południe smakuje malinowym sokiem, / którego babcia dolała do kanek z wodą" (z wiersza Żniwa, s. 14) oraz „Upchany ciasno w neseser wagonu, I nieważki w zbitej masie" (z wiersza Droga Pana Incognito, s. 52) ${ }^{\mathbf{1 9}}$. Pierwszy cytat odnosi się do chwil z dzieciństwa spędzanego na wsi, drugi - do dorosłości w anonimowym sektorze miejskim. Oba - jak widzimy - doskonale reprodukują antymodernistyczne ideologie estetyczne.

Wołoszyn wpisuje się swoim debiutem w rozumienie poezji jako zbioru umiejętności, reguł i idei, których raczej się nie kwestionuje, choć można je transponować w bardziej aktualne konteksty. Spłaca też swoim zbiorem emigracyjny dług - to wieś (polska) staje się matecznikiem wartości, których - jak moźna się domyślać - brakuje współczesnemu światu.

Jeśli pozycja poety według Rybickiego sprowadza się do prowokowania kryzysów w strukturach, to Wołoszyn przeznacza dla poety/artysty rolę moralisty i edukatora. Kluczowe dla działań Rybickiego zerwanie z rutyną codzienności, odnajdywanie swobody ekspresji na obszarach dotąd zarezerwowanych dla skodyfikowanych reguł językowych pozwala uznać jego

19 G. Wołoszyn Poliptyk, Miejska Biblioteka Publiczna im. Cypriana Kamila Norwida, Świdnica 2012. 
poezję za inscenizowany happening o absurdalno-surrealnym charakterze. Stanowisko Wołoszyna, preferujące komunikację w obrębie pewnej wspólnoty - z uprzywilejowanymi ideami, medium oraz wartościami - sugeruje myślenie o poezji jako sztuce utrzymującej niejako z zasady przewagę w grze estetycznej nad innymi trybami artystyczności (wyższość wywiedziona z romantycznej hierarchii sztuk). Powoduje to, że poezję, będącą u tego autora swoistym metajęzykiem współczesności, paradoksalnie trzeba uznać za wyłączoną ze świata współczesnego i odseparowaną od jego przemian m.in. technologiczno-cywilizacyjnych. Być może tę różnicę w podejściu dwóch autorów do wyobrażeń na temat poezji najlepiej określałoby stanowisko wobec estetyczno-artystycznych doświadczeń nowoczesnej poezji: albo się te doświadczenia bierze pod uwagę, albo nie.

\section{Kierunek: wieś}

Nie tylko Grzegorz Wołoszyn w Poliptyku zaangażował się w przedstawienie polskiej wsi. Mitologia wiejskości decyduje też o ustawieniu sensów w poezji Wioletty Grzegorzewskiej ${ }^{20}$ i Tomasza Mielcarka.

Wiersze Grzegorzewskiej mają wiele wspólnego z jej prozą (Guguty 2014) oraz z autobiograficznymi zapisami z Notatnika z wyspy (2012). Przestrzeń wiejska w tomach Orinoko (2008), Inne obroty (2010) czy Ruchy Browna (2011) nacechowana jest znaczącą ambiwalencją, której u Wołoszyna próżno szukać. Autorka, mieszkająca w Ryde, w Nowej Walii, utrzymuje swoje wiersze najczęściej w konwencji reportersko-dokumentalnej, choć znajdziemy u niej także utwory surrealistyczno-baśniowe. Ta rzeczowa dokumentalność, będąca czymś w rodzaju anegdotycznych szczegółów lat 8o., dominując w opisach wsi (Czarnobyl, popularne w PRL-u zimowe buty Relaks, motor WSK) mogłaby świadczyć, o tym, że Grzegorzewska - podobnie jak Wołoszyn próbuje wyzyskać „tożsamościowe” tradycje poezji. Jednak, nawet jeśli często w tych wierszach obrazy powoływane są w genealogiczno-rodzinnym

20 Nie jest dla nikogo niespodzianką, że polska literatura po roku 2000 nie zrobiła furory na Wyspach Brytyjskich. Polskie młode poetki i młodzi poeci także nie są znaczącymi autorami/autorkami dla czytelników anglojęzycznych (pomijając fakt ogólnej słabej pozycji poezji w notowaniach czytelniczych). Chlubnym wyjątkiem jest książka Finite Formule \& Theories of Chance Wioletty Grzegorzewskiej, która w przekładzie Marka Kaźmierskiego była w 2015 roku nominowana do Griffin Poetry Prize i znalazła się na tzw. krótkiej liście. Grzegorzewska jest autorką także innych zbiorów wierszy, jednak mnie interesują te, które pisze od roku 2006, przebywając poza Polską. 
wspomnieniu, to między piszącą a pokazywanymi sytuacjami, panoramami i pejzażami następuje ciekawe rozsunięcie. Sprawia ono, że wiersze dają się odczytywać jak faktograficzne zapisy folklorystycznych ujęć chłopskiej kultury. Grzegorzewska zachowuje się więc jak dokumentalistka, przekazująca wiedzę o tym obszarze: opowiada o chłopskich zwyczajach z perspektywy wiedzy o innych kulturach. Gdy opisuje np. zwyczaj „chodzenia po domach ze świętym obrazem", pokazuje sceny z kilku perspektyw, potraja i podwaja głosy, mimo zachowania monologowego charakteru wiersza. Symptomatycznie też brzmią zdania z Notatnika z wyspy o widmowym domu:

Nie pytajcie mnie, dlaczego nie wróciłam do Polski. Nie mieszkam w Ryde na wyspie Wight ani w miasteczku o tej samej nazwie w Nowej Południowej Walii. Zawsze znajdziecie mnie w widmowym domu mojego ojca, który latami budował na łące, gdzie zakwitają dziewięćsiły bezłodygowe. ${ }^{21}$

Co prawda, wieś nie jest u autorki Innych obrotów politycznie (ekonomicznie-klasowo) pokazywana, ale nie jest też mitologizowana (muzealizowana) na wzór arkadyjsko-pastoralny. Za tę otwartą estetykę wiersza odpowiada moim zdaniem kolekcjonerska, o feministycznym zabarwieniu, pasja Grzegorzewskiej. Swobodniejszy stosunek do własnej przeszłości, prawie rewizjonistyczny, wzmacnia tu chęć pomnażania kolekcji (obrazów, przeżyć,światów, idei), a nie chęć ich ograniczania na rzecz zachowania czystości rodowodu. Stąd ważny aspekt nierealności tych obrazów, ale i ich, by się tak wyrazić, wydajność kulturowa. Wiersz Grzegorzewskiej jest pewnego rodzaju kompromisem między wierszem rozumianym jako wyznanie indywidualnego podmiotu i wartością wynikającą ze społeczno-kulturowego rozumienia sztuki. Dlatego te utwory najciekawiej byłoby analizować jako przykład świadomości cross-kulturowej. Zawierają one bowiem sojusze z różnymi znakami i dalekie są zwłaszcza od tego, by czynić z tych znaków totemy, o których znaczenia należy walczyć z innymi kulturami. Dowodem znakomite zdanie z Notatnika z wyspy: „Kwefy, czarczafy, jaszmaki na głowach muzułmańskich kobiet są tak zwyczajne jak chustki twojej prababki i czapka z rebooka"22.

W wierszach Tomasza Mielcarka z debiutanckiego zbioru Obecność (2014) wiejskie obrazy stają się natomiast komponentem przekonań o naturalistyczno-biologicznych podstawach życia. Stopniową, ale systematycznie

21 W. Grzegorzewska Notatnik zwyspy, e-media, Częstochowa 2012, s. 58.

22 Tamże, S. 47. 
postępującą erozję ludzkiego świata Mielcarek pokazuje w quasi-obiektywistycznych wierszach. Te sceny ludzkiego świata konfrontowane z przyrodniczym niewzruszeniem mają kierować naszą uwagę na sprawy metafizyczne: światło, wielkie interwały czasu, ludzką śmiertelność i bezradność wobec tej śmiertelności. Ciekawe, że zawsze taka deterministyczna filozofia życia występuje w ramach sztuki pomyślanej jako kulturowa, a nie jako adaptacyjna czy naturalna aktywność artystyczna ${ }^{23}$. Jest ona jednak oczywiście „naturalizowana", ponieważ inaczej trudno byłoby jej zachowywać tę specyficzną właściwość aktywności niby-ludzkiej, ale poza ludzką perspektywą. Poezja Mielcarka dzieli wszystkie sprzeczności tak pomyślanej konserwatywno-elitarnej koncepcji sztuki. Przede wszystkim w swojej totalizującej rozciągłości znosi inne, historyzujące punkty widzenia i nie pozwala na pewne pytania, np. - dlaczego ci wszyscy opisywani w wierszach ludzie: bezdomny zjedzony przez psy, stara kobieta drętwiejąca w bezruchu, wariatka z parteru, robotnicy etc. nie mają dostępu do tej gorzkiej wiedzy, którą ma mówiący podmiot. I czy robotnicy z wiersza Poranek, których podsłuchuje wybudzający się ze snu podmiot, muszą opowiadać sobie historie z tanich burdeli? Nie mogliby np. zwiedzać muzeów?

Poezja i projektowane w jej obrębie obrazy wiejskiej egzystencji stają się w wierszach z tego tomu rozrusznikiem dla „uniwersalistycznej” konwencji, która - by przekonywała - musi ukrywać swoją historyczność. Wyrażają one idee zgodne m.in. z egzystencjalną filozofią: na całym świecie i w różnych czasach ludzie są śmiertelni. Dlatego obrazy z polskiej wsi są tu pretekstowe, mogłyby pochodzić z zupełnie innych miejsc. Mają wyłącznie posłuźyć do namysłu nad ludzkim życiem (życiem „w ogóle”) i nie mogą kierować naszej uwagi na ekonomiczno-polityczny konkret, nie mogą teź stanowić punktu wyjścia kulturowej refleksji. Nieucieleśniona (uniwersalistyczna) perspektywa w wierszach Mielcarka wyrasta oczywiście z zupełnie innych tradycji myślenia o podmiocie i sztuce niżidee tranzy towości w poezji Rybickiego czy wieloperspektywiczność widzenia kulturowego w poezji Grzegorzewskiej; pewne pokrewieństwo może łączyć ją natomiast z wierszami Wołoszyna. Obie propozycje poetyckie zdają się wyłaniać z tych samych przeświadczeń o uniwersalnych wartościach sztuki oddzielonej od aktualnych warunków powstawania.

23 Zob. J. Luty Sztuka jako kategoria naturalna, w: Estetyka pośród kultur, red. K. Wilkoszewska, Universitas, Kraków 2012, s. 116-129. 


\section{Poezja więlkszości}

Wiersze pozostałych autorów - Małgorzaty Południak, Izabeli Smolarek, Kajetana Herdyńskiego, Arkadiusza Kremzy - można by scharakteryzować, uogólniając oczywiście, jako różne warianty poezji „mówionej”, nastawionej głównie na konwersacyjny tryb. Ich miejskość jest niewątpliwa, choć niespecjalnie uderzająca, stanowi po prostu naturalne środowisko dla różnych językowych rozwiązań. To poezja zderzeń sytuacji, mikrodialogów, wymiany zdań, korzystająca z monologu, który jednak lirycznym trudno byłoby nazwać - rzadko chodzi w niej o odcinanie się od potocznego języka, częściej o naśladowanie mowy zwyczajnej, inteligentny żart, celną ripostę, błyskotliwe skojarzenia. Nie tyle rozpracowuje się tu język w obrazach (zmysłowo-plastycznych, jak u Grzegorzewskiej, czy futurystyczno-architektonicznych, jak u Rybickiego), ile w ogóle najczęściej rezygnuje z zarysowania tła czy planu wypowiedzi. Wspomniani autorzy dążą do nawiązania bardziej bezpośredniego kontaktu z czytelnikami, stawiają na indywidualnie pomyślany podmiot - refleksyjny, krytyczny, emocjonalnie zaangażowany w język. I tak Kajetan Herdyński, autor zbioru wierszy Późny karnawat (2012), dyskretnie aluzyjny i wielopoziomowy, przywiązuje dużą wagę do rytmu, powtórzeń, zgrabnych chwytów językowych. Mimo realistycznego trybu pisania wiersze Herdyńskiego dają się czytać jako opowieści o filmowo-popowej miejskości: z jej różnymi bohaterami, legendami i typowymi nastrojami. Małgorzata Południak - autorka zbioru Czekając na Maline (2012) - do pisanego już w Irlandii zbioru Liczby nieparzyste (2014) wprowadza wiersze dające efekt intymności, rodzinnych zwierzeń, osobistych historii etc. Na większej niezgodzie ze światem buduje profil kobiecego podmiotu swoich wierszy Izabela Smolarek, autorka się lenienia (2006). Te trzy propozycje są rozpisanymi w różnych tonacjach wariantami autobiograficzności, która ma zmieścić tzw. sytuacje z miejskiej codzienności i opowieści o relacjach między bliskimi sobie ludźmi.

Poezja Arkadiusza Kremzy, autora wielu zbiorów wierszy, w tym napisanych w Anglii Ludzi wewnętrznych (2009), Wierszy z wody iżelaza (2012) i częściowo też Sterowni (2015) najbardziej odbiega od wzoru wiersza-rozmowy. Przykładowo w książce-poemacie Ludzie wewnętrzni, skomponowanym jako seria odezw do tytułowych bohaterów, Kremza pokazuje psychologiczne zapętlenia i społeczne samooszustwa. Jego książki opierają się też najczęściej na koncepcie ciekawie organizującym całość. Co istotne, Kremza nie ogranicza w swoich wierszach przedstawiania rzeczywistości społeczno-psychicznej do związków typu realistycznego, ale pozwala na nieco swobodniejsze wiązania między materialnością i duchowością, faktycznością i potencjalnością etc. 


\section{Limit play}

Jak widać, nieczęsto sięga się w wierszach pisanych za granicami Polski po romantyczno-nostalgiczny kod, ale nadal dominuje w nich strategia lirycznego wyznania. Tak jakby na emigrację do Wielkiej Brytanii wyjechali przede wszystkim użytkownicy języka polskiego, dla których kultura (poezja) jest sferą nieprzylegającą do sfery społeczno-politycznej w jej aktualnym wymiarze: problemów z władzą, pieniędzmi, organizacją pracy i czasu wolnego; i to oni - zdolni polonistycznie uczniowie zapełniają ulice Wielkiej Brytanii, a nie ludzie wykluczeni, ekonomicznie zmarginalizowani czy społecznie wzburzeni, mogący uznać sztukę za doskonałe narzędzie do produkowania obrazów o politycznych konsekwencjach. Idea poezji, jaka wyłania sięz książek tych autorów $\mathrm{i}$ autorek, związana jest przede wszystkim z wartościami tożsamościowymi w perspektywie indywidualnej, rzadziej włącza się tu perspektywa klasowa, płciowa czy obywatelska. Taka idea poezji ściślej łączy się także z wartościami konserwatywnymi niż awangardowo-progresywnymi: podtrzymanie związku z przeszłością najczęściej staje się podstawowym przekonaniem formułowanym przez rozpowszechnianie określonych rejestrów języka i tradycji. Panuje więc przeświadczenie, że poezja to sprawa indywidualnej wraźliwości, autobiograficznego wyznania, nostalgicznego wspominania przeszłości.

Poeci i poetki w większości okopali się w językach preferujących bezpośrednią ekspresję literacką i wobec różnorodnych przemian sfery komunikacyjno-politycznej pozostają kompletnie obojętni. W gruncie rzeczy nie bardzo wiadomo, co stanowi trudność artystyczno-ideową dla takich autorów jak Grzegorz Wołoszyn czy Tomasz Mielcarek, oczywiście poza kwestią podtrzymania iluzji dawnej pozycji poezji. W takiej perspektywie, jaką proponują, wartość np. idei wiejskości pozostaje niejasna, skoro poezja ma reprezentować wartości pozaczasowe. Utrzymanie dawno wypracowanych sposobów rozumienia poezji wydaje się najbardziej charakterystyczną cechą wierszy powstających za granicą i niewiele autorek/niewielu autorów stara się wypracowywać nowe warunki i konteksty, w ramach których poezja mogłaby funkcjonować. Nie chodzi jedynie o to, że w swoich wierszach prawie zawsze korzystają oni z historycznego wzorca w sposób niekrytyczny, ale o to, że sposób myślenia o poezji, jaki wyłania się z tych wierszy, izoluje ją od zjawisk społeczno-komunikacyjnych i od innych wytworów kultury. Chodziłoby więc - formułuję to jako postulat ze strony kry tyki - o takie rozszerzanie rozumienia poezji, które umieszczałoby ją nie tylko w sferze osobistej ekspresji, ale także w perspektywie kulturowej. 
Warto podkreślić jeszcze jedną rzecz, najbardziej uderzającą. Z paroma wyjątkami, poeci i poetki przebywający za granicami Polski nie konfrontują się w ogóle z poezją pisaną w kraju ich aktualnego pobytu. To z polskimi tradycjami sprzymierzają się jeszcze silniej, mniej reagując na możliwe doświadczenia innego sposobu zorganizowania przestrzeni. Z wyjątkiem Grzegorzewskiej i Rybickiego nie mamy do czynienia w tych książkach ani z konkretem obyczajowo-lokalnym, który stanowiłby punkt wyjścia obserwacji międzykulturowych spotkań, ani z włączaniem poezji w ponadpartykularne idee, m.in. wirtualności, technologii, politycznych wypowiedzi, mniejszościowych racji. Trzymanie się z dala od innych kultur jest najbardziej negatywnym wnioskiem, jaki można wysnuć z obserwacji tej poezji, zakotwiczonej najsilniej - podkreślam, z kilkoma wyjątkami - w myśleniu o kulturze pojętej przede wszystkim przez pryzmat narodowego monolitu. Tymczasem, nawet jeśli zasady finansowania sprzyjają ujmowaniu kultury po Herderowsku homogenicznej, to trzeba pamiętać, że - jak przypomina Wolfgang Welsch - historyczne ruchy artystyczne nigdy nie były narodowe, szły w poprzek takim podziałom ${ }^{24}$. Na razie poezja autorek $i$ autorów, żyjących na przecięciu kultur i mogących obserwować z bliska życie w innych krajobrazach, okazuje się bardziej przywiązana do monolitycznego i konserwatywnego modelu kultury niż poezja powstająca w Polsce. Przywiązana jest też do tradycyjnych przekonań estetycznych. Być może to powinno skłonić nas do analizowania tej poezji nie tylko w kategoriach estetyczno-artystycznych, działających w polu sztuki. Bardziej zasadne byłoby przyglądanie się jej w ramach kulturowych praktyk codzienności i szukanie pokrewieństwa z innymi praktykami społecznymi, potrzebnymi do wytwarzania poczucia wspólnoty, organizowania życia i komunikacji.

24 Zob. W. Welsch Tożsamość w epoce globalizacji- perspektywa transkulturowa, przeł. K. Wilkoszewska, w: Estetyka transkulturowa, red. K. Wilkoszewska, Universitas, Kraków 2004, s. 37. 


\section{Abstract}

\section{Anna Kałuża}

UNIVERSITY OF SILESIA (KATOWICE)

Polish Poetry on the Isles: In the Evenings We Feel Nostalgic

Kałuża describes the communicational conditions, politico-cultural perspectives and aesthetic or artistic approach to poems in the work of Polish poets residing outside Poland. As a point of departure she proposes to substitute twenty-first-century emigre narratives with notions of cultural encounters and everyday writing practices. Based on an analysis of both the poems and the traditions in which they are rooted, Kałuża proposes her principal thesis that these works are tied to a monolithic and conservative model of culture.

\section{Keywords}

Polish poetry, emigration, translation of cultures, aesthetic game, mythology of the village 